\section{Nyttig og oppdatert lærebok om smerte}

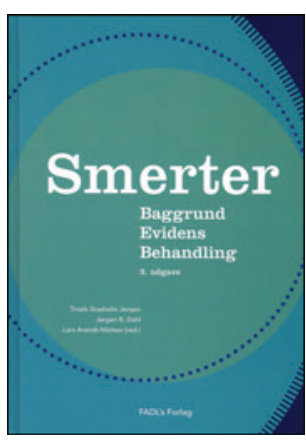

Troels Staehelin Jensen, Jørgen B. Dahl, Lars Arendt-Nielsen, red.

Smerter

Baggrund - Evidens - Behandling. 3. utg. 419 s, tab, ill. København: FADL's Forlag, 2013. Pris DKK 550

ISBN 978-87-7749-703-2

Tredje revisjon av Smerter foreligger. Redaktørene har invitert 46 forfattere fra fagene medisin, odontologi, psykologi, fysioterapi, kiropraktikk og sykepleie til å bidra med 28 korte kapitler, noe som sikrer en bred og god oppdatering. Et stort antall forfattere fører til en viss grad av gjentakelser og overlapping, men uten at dette sjenerer når leseren bruker boken som oppslagsverk.

Boken er skrevet på dansk og selges i innbundet form med en enkel og streng layout. Til tider kan figurene fremstå noe fargefattige, men de bidrar i sin enkelhet til at stoffet blir tilgjengelig for flere faggrupper. Leseren får dessuten gjennom oversiktlige tabeller detaljert oversikt over hvilke medikamenter som er aktuelle ved de ulike formene for smerte.

Rekkefølgen av enkelte kapitler fremstår dessverre tilfeldig, og det er påtagelig at psykologisk smertebehandling ender opp sist i rekken av behandlingsformer. At man ved behandling av kroniske lenderyggsmerter fremhever betydningen av pasientinformasjon, men i kapitlet om nevropatisk smerte kun fokuserer på farmakoterapi, reflekterer også hvordan tilfeldige tradisjoner i de ulike fagfeltene preger medisinsk praksis. I omtalen av omdiskuterte behandlinger som kiropraktikk og manipulasjon, balanserer forfatterne forbilledlig og skiller mellom eksisterende modeller og vitenskapelig funderte teorier. Mindre invasive behandlingsformer er imidlertid utelatt, for eksempel radiofrekvensablasjoner ved fasettleddsrelatert smerte. Boken er også ufullstendig når det gjelder rutiner ved epidural smertebehandling av nyopererte pasienter som samtidig behandles med blodfortynnende/platehemmende substanser. I kapitlet om viscerale smerter og opioider savner jeg en sterkere betoning av problemet «narcotic bowel syndrome», som i liten grad er kjent blant dagens helsearbeidere.

Smerter utgjør i dag en av de hyppigste årsakene til at pasienter søker helsehjelp. Denne læreboken er derfor et viktig tilskudd til undervisningen av både studenter i medisin, sykepleie og fysioterapi. Samtidig fremstår den som et nyttig oppslagsverk for allmennpraktiserende leger og «organleger» innen spesialisthelsetjenesten.

Gunnvald Kvarstein

Universitet i Tromsø

\section{Litt om alt}

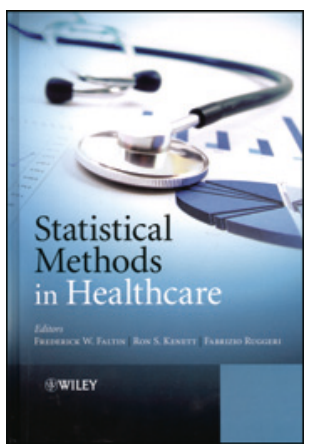

Frederick Faltin, Ron Kenett,

Fabrizio Ruggeri, red.

Statistical methods in healthcare

491 s, tab, ill. Chichester: Wiley-Blackwell, 2013. Pris GBP 80

ISBN 978-0-470-67015-6

La det være klart med en gang - dette er ikke en lærebok i statistikk. Fra jeg startet på første kapittel undret jeg meg over hvem denne boken egentlig er ment for. Det fikk jeg faktisk aldri helt klart for meg - til det favner boken for vidt. Redaktørene slår et slag for at helseforskningen, og spesielt helsetjenesteforskningen, bør utnytte statistiske metoder til kvalitetskontroll og kvalitetsforbedring som vi normalt forbinder med kontroll av produksjonslinjer, men de begrenser seg ikke til dette temaet.

Bidragsyterne begynner med å ta for seg en oversikt over legemiddelmyndighetenes retningslinjer med søkelys på statistisk analyse, og de fortsetter med å beskrive bruk av statistiske metoder i kliniske utprøvninger og utvikling av nye legemidler. Deretter følger temaer som systematiske effektanalyser («outcomes analysis») og statistisk prosesskontroll. Den siste halvdelen omhandler bruk av statistikk i helsetjenesten og problemstillinger som spenner fra kostnader til styring. Noen av kapitlene er relativt smale og viet enkeltprosjekter og doktorgradsarbeider, for eksempel en modell for optimalisert tildeling av nyrer til pasienter på venteliste for transplantasjon. Andre kapitler er mer generelle og omtaler for eksempel kostnad-nytte-analyser eller romlig statistikk og sykdomskart. Enkelte kapitler er lettleste og fri for matematiske formler, mens andre krever en del av leseren med hensyn til matematisk kompetanse.

Det finnes en mengde faglitteratur som dekker alt fra elementær til avansert statistisk metode til bruk i klinisk og epidemiologisk forskning. Her har forfatterne en annen tilnærming, og de tar for seg helt andre emner enn man gjør i de tradisjonelle lærebøkene. Trolig er boken først og fremst ment for statistikere som arbeider innen helsetjenesteforskning. Forskere med medisinsk eller annen helsefaglig utdanning bør være fortrolig med, og opptatt av, statistisk metode for å ha glede av boken. For mange av kapitlene kreves en del forhåndskunnskap for at man skal kunne ha utbytte av lesingen, og boken egner seg i liten grad som en introduksjon til de forskjellige emnene. Teksten går for øvrig sjelden virkelig i dybden. Det lar seg heller ikke gjøre når man favner så bredt som her.

Er det dermed bortkastet lesing? Absolutt ikke, men etter min oppfatning spriker temaene i litt for mange retninger. Boken er bedre egnet som et oppslagsverk eller en idébank enn som en bok man leser fra perm til perm.

Eva Skovlund

Nasjonalt folkehelseinstitutt 